\title{
sciendo
}

Current Issues in Pharmacy and Medical Sciences

Former ly ANNALES UNIVERSITATIS MARIAE CURIE-SKLODOWSKA, SECTIO DDD, PHARMACIA

\section{Effect of Achillea santolina essential oil on bacterial biofilm and its mode of action}

\author{
Jehad Al-Shuneigat ${ }^{1 \star} \bullet$, Sameeh Al-Sarayreh ${ }^{1} \oplus$, \\ Yousef Al-Saraireh ${ }^{2} \odot$ MAHMoud Al-Qudah $^{3}$
}

\author{
${ }^{1}$ Department of Biochemistry and Molecular Biology, Faculty of Medicine, Mutah University, Mutah, Jordan \\ 2 Department of Pharmacology, Faculty of Medicine, Mutah University, Mutah, Jordan \\ ${ }^{3}$ Department of Chemistry Faculty of Science, Yarmouk University, Irbid, Jordan
}

\section{ARTICLE INFO \\ Received 26 September 2019 \\ Accepted 28 October 2019}

\section{Keywords:}

Aantibacterial,

antibiofilm,

Achillea santolina,

mode of action,

essential oil.

\begin{abstract}
Increased multidrug resistance prompted researchers to search for a new drug that has the ability to overcome antibiotic resistant pathogens. Essential oils have been used in folk medicine for centuries, therefore, they could be employed as an effective alternative to antibiotics without having secondary side effects.

The aim of the present study was to test the antibacterial and antibiofilm activity of the essential oil of Achillea santolina and to ascertain its mode of action.

Minimum Biofilm Inhibitory Concentration (MBIC) susceptibility assays were performed using a biofilm inoculator with a 96-well plate with peg led. Minimum Inhibitory Concentration (MIC) was performed in normal microtitre plates using a twofold dilution series.

Achillea santolina essential oil (ASEO) was able to overcome the resistance of all tested bacteria. The MIC values were in the range of $250-1000 \mu \mathrm{g} / \mathrm{ml}$, while the MBC values were in the range of $500-2000 \mu \mathrm{g} / \mathrm{ml}$. ASEO increased leakage of potassium ions from the cell membrane and increased release of cellular materials - suggesting that the cell membrane is the target and site of action of ASEO. Moreover, ASEO was able to inhibit initial adherence of methicillin-resistant Staphylococcus aureus (MRSA) (ATCC 43300) at sub-inhibitory concentrations through alterations to cell membrane.
\end{abstract}

\section{INTRODUCTION}

The emergence of resistant bacteria has become a major health problem worldwide. Antibiotics misuse and overuse are believed to be behind antibiotic resistance. The existence of multidrug-resistant (MDR) bacteria or "superbugs" is a growing threat worldwide. About 70,000 people die each year worldwide from infections caused by antibioticresistant pathogens [1].

Methicillin-resistant Staphylococcus aureus (MRSA) kills more USA citizens each year than AIDS, Parkinson's disease, emphysema and homicide combined. The global spread of drug resistant Staphylococcus aureus, Pseudomonas aeruginosa, Mycobacterium tuberculosis, Acinetobacter and Enterococcus species poses the biggest threat [2].

The organization of bacteria into biofilms increases their ability to resist antibiotics. Bacterial biofilm is a

\footnotetext{
* Corresponding author

e-mail: Dr.Jehad@mutah.edu.jo
}

group of microbial cells attached to a surface and enclosed in matrix of extracellular polymeric biomolecules [3]. The matrix which occupies $80-85 \%$ of the biofilm's volume is composed of polysaccharides, proteins, lipids and DNA. The matrix provides structural stability and protection to the biofilm. Over $90 \%$ of bacteria form biofilm and about $65 \%$ of microbial infections are associated with biofilms $[4,5]$. Biofilms can be formed by single or multiple microbial species. Biofilm can occur on different surfaces, including teeth, heart valves, lungs of cystic fibrosis patients, middle ear, intravenous catheters and stents [6]. Bacterial biofilms show extreme tolerance to antimicrobial agents (as these cause chronic infections) and to hostile environmental conditions like starvation. Microbes in biofilms can be a thousand times more tolerant to antimicrobial agents than planktonic ones [7,8]. Additionally, microbes in biofilms are protected against the host immune system through impaired activation of phagocytes and the complement system [9]. Infections caused by biofilms, including 
endocarditis, cystic fibrosis, and indwelling device mediated infections, are often untreatable and develop into a chronic state [5].

Biofilm resistance can be attributed to many reasons, including restricted antibiotic penetration, higher rate of mutation, decreased growth rates, nutrient and oxygen availability to the bacterial cells and increase in expression of efflux pumps $[4,10]$. Bacterial biofilm formation begins with reversible attachment to a surface. This is followed by irreversible binding to the surface and the formation of microcolonies and production of polymer matrix around the microcolonies [11]. The biofilm initial attachment step depends on interactions between microbial cell surface and attachment surface, including electrostatic and hydrophobic interactions, steric hindrance and van der Waals forces. It is believed that hydrophobic interaction is the main player in the initial attachment step $[12,13]$.

Essential oils are volatile, natural compounds that are formed by aromatic plants as secondary metabolites. Essential oils are known for their antibacterial, antiviral, antifungal, antioxidant and antiseptic effects, beside sedative, pain relief, aromatherapy and anti-inflammatory attributes [14]. Essential oils are used in fragrance and make-up products, in sanitary products, as food preservers, flavors and additives and as natural medicine $[15,16]$. Naturally, essential oil protects plants from different pathogens. Achillea santolina is a medicinal plant with aromatic smell. In traditional medicine it is used for antidiabetic, antidiuretic, antiinflammatory, hypertension and antimicrobial effects. It is also used against gastrointestinal disorders and to relieve colic and symptoms of common cold.

The increase in microbial resistance to antibiotics, besides the known issues of drug side effects, increases the need for new drugs. The microbial resistance to known antibiotics increases the need for new drugs that are different from that currently in use [17]. Essential oils have been reported to exhibit antimicrobial activity. They are cheap, easily available, do not exhibit side effects and are able to overcome the resistance of many pathogen due to their multiple mechanisms of action [18].

The aim of the present study was to test antibacterial and antibiofilm activity of essential oil of Achillea santolina, and to ascertain its mode of action.

\section{MATERIALS AND METHODS}

\section{Essential oil of Achillea santolina}

The chemical composition of the Achillea santolina was previously published by our research group [19]. In short, fresh aerial parts of Achillea santolina was collected, from Mutah Alkarak, south Jordan, then finely chopped and subjected to hydrodistillation using a Clevenger-type apparatus. Chemical analysis of the essential oils was carried out by applying gas chromatography-mass spectrometry (Agilent (Palo Alto, USA) 6890N gas chromatograph). Identification of the oil components was based on computer search using the library of mass spectral data and comparison of calculated Kovats retention index (KRI) with those of available authentic standards and literature data.
Forty-six components accounting for $100 \%$ of the oil were identified. The major identified compounds were transSabinene hydrate acetate $-30.09 \%$, Iso-Ascaridole $-16 \%$, $\alpha$-Terpinene $-14.31 \%$, p-Cymene $-7.1 \%$, cis-Carvone oxide $-6.08 \%$, Terpinen-4-ol $-2.75 \%$, cis-Pulegol $-2.58 \%$, cis-Rose oxide - $2.31 \%, 1$-Terpineol - $1.93 \%$, Z- $\beta$-Ocimene $-1.9 \%$, trans-Verbenol $-1.88 \%$, and trans-Piperitol $-1.52 \%$.

The major oil components were oxygenated monoterpene $-70.22 \%$, monoterpene hydrocarbon $-26.95 \%$, and sesquiterpene hydrocarbon $-1.04 \%$.

\section{Maintenance and Preparation of Cultures}

The effect of Achillea santolina essential oil (ASEO) on bacterial biofilm was examined using six bacterial strains: Staphylococcus epidermidis (ATCC 35984), Methicillinsusceptible Staphylococcus aureus (MSSA) (ATCC 25923), Methicillin-resistant Staphylococcus aureus (MRSA) (ATCC 43300), Pseudomonas aeruginosa (ATCC 27853), Escherichia coli (ATCC 25922), and the non-biofilm forming strain Staphylococcus epidermidis (ATCC12228). Cultures were stored on tryptone soya agar (TSA) (Oxoid, Hampshire, UK) at $2-4^{\circ} \mathrm{C}$ and subcultured every 3-4 weeks or whenever required.

\section{Minimum Inhibitory Concentration (MIC)}

MIC was determined using 96 well broth microdilutions described by Rachid et al. [20]. ASEO stock solutions were prepared by dissolving the essential oils in dimethyl sulfoxide (DMSO) (Carlo Erba, France). The stock solutions of ASEO in DMSO were diluted in TSB to give EO concentrations of $16000 \mu \mathrm{g} / \mathrm{ml}$. Two fold serial dilutions of ASEO in tryptone soya broth (TSB) (Oxoid, Hampshire, UK), were then carried out in microtitre plates to give essential oil concentrations of $8000,4000,2000,1000,500,250$, and $125 \mu \mathrm{g} / \mathrm{ml}$.

Bacterial cells were grown overnight to mid-log phase by inoculating TSB $(100 \mathrm{~mL})$ and incubating at $37^{\circ} \mathrm{C}$ until the $\mathrm{OD}$ at $600 \mathrm{~nm}\left(\mathrm{OD}_{600}\right)$ reached approximately 0.6 , then diluting to $1 \times 10^{6} \mathrm{cfu} / \mathrm{m}$ and seeding $(100 \mu \mathrm{L})$ to the wells containing ASEO, mixing and incubating at $37^{\circ} \mathrm{C}$ for $24 \mathrm{~h}$ aerobically. The MIC was taken as minimal concentration of ASEO that inhibited visible growth of the strain. Determination of MIC was carried out in triplicate using three independent experiments.

\section{Minimum bactericidal concentration (MBC)}

To determine the $\mathrm{MBC}$ values, a volume of $30 \mu \mathrm{L}$ from each well that did not show an apparent growth as confirmed by MIC determination, was taken and plated on TSA agar. The plates were subsequently incubated at $37^{\circ} \mathrm{C}$ for $48 \mathrm{~h}$. The MBC was defined as the lowest essential oil concentration able to reduce and kill more than $99.9 \%$ of the initial inoculum [21].

\section{Minimum Biofilm Inhibitory Concentration (MBIC) Assay}

Biofilm susceptibility assays were performed using MBIC (Minimum Biofilm Inhibitory Concentration) (Innovotech, Inc., Edmonton, AB, Canada), a biofilm inoculator with 
a 96-well plate (Figure 1), according to the method reported by Ceri et al. [22]. Bacterial strains were cultured overnight in tryptone soya broth (TSB) (Oxoid, Hampshire, UK) and then diluted to give a final concentration of $1 \times 10^{6} \mathrm{cfu} / \mathrm{mL}$. After this, $150 \mu \mathrm{L}$ of inoculums was added to each well of 96-well MBEC biofilm inoculators and the peg lid was then fitted onto the plates. After $24 \mathrm{~h}$ incubation at $37^{\circ} \mathrm{C}$, biofilms were formed on the pegs. Peg lids were then rinsed three times in phosphate-buffered saline (PBS) (Sigma Aldrich) to remove non-adherent cells, and then the peg lid was transferred to a new 96-well plate containing serially diluted essential oil. The microtiter plate was then incubated at $37^{\circ} \mathrm{C}$ for $24 \mathrm{~h}$. Following incubation with essential oil, the pegs were rinsed three times with PBS and placed in a fresh 96-well plate containing $100 \mathrm{~mL}$ of TSB (recovery plate). The bacteria were removed from the pegs by sonicating the plates for 5 min on high speed with a Decon F51 006 sonicator. The peg lids were then discarded and replaced with standard lids. The OD650 was measured before and after incubation at $37^{\circ} \mathrm{C}$ for $6 \mathrm{~h}$. Biofilm susceptibility assays were carried out in three independent experiments in triplicate for each strain. OD650 value of 0.05 was regarded as absence of biofilm. The minimum biofilm inhibitory concentration (MBIC) value was read as the concentration of essential oil that inhibited visible growth of bacteria confirmed by no increase in optical density compared with the initial reading. A shift in susceptibility of more than two doubling dilutions in either direction was considered to be a significant change.

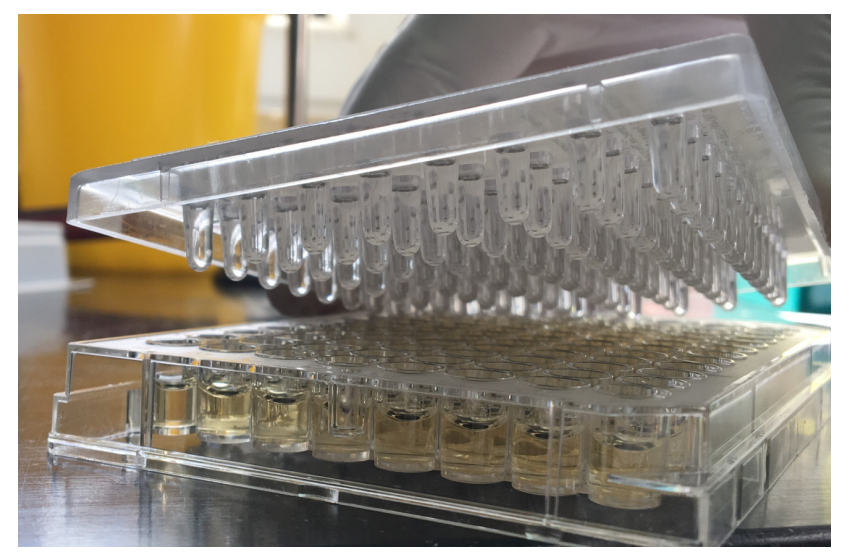

Figure 1. Biofilm inoculator with a 96-well plate with peg lids (Innovotech, Inc., Edmonton, $\mathrm{AB}$, Canada)

\section{Minimum Biofilm Eradication Concentration (MBEC)}

The MBEC values was determined by taking a $30 \mu \mathrm{L}$ volume from each well that did not show an apparent growth as confirmed by MBIC determination, then plating this on TSA agar. The plates were incubated at $37^{\circ} \mathrm{C}$ for $48 \mathrm{~h}$. The MBEC was defined as the lowest essential oil concentration at which no bacterial growth occurred on the TSA plates.

\section{Leakage of Potassium Ion}

The leakage of potassium ion $\left(\mathrm{K}^{+}\right)$into the bacterial suspension was measured using a Kalium/Potassium kit (Quantofix, Macherey-Nagel GmbH \& Co. KG, Duren, Germany). S. epidermidis (ATCC 35984), MRSA (ATCC 43300), P. aeruginosa (ATCC 27853), and E. coli (ATCC
25922) were exposed to essential oils at MIC value in sterile peptone water $(0.1 \mathrm{~g} / 100 \mathrm{~mL})$. The extracellular potassium concentration was measured at $0,30,60,90,120$, and 240 minutes. A culture flask without AEO was used as a control. Results were reported as the amount of free potassium ion $(\mathrm{mg} / \mathrm{L})$ in the bacterial suspension at each time interval.

\section{Integrity of the Cell Membrane (Release of cellular material)}

The function of the cell membrane is to hold different components of the cell together and protect it from the extracellular environment. Thus, the release of cellular materials, especially DNA, RNA and proteins outside the cell indicates damage within the cell membrane. Essential oils at the MIC concentration were added to $2 \mathrm{~mL}$ of $S$. epidermidis (ATCC12228), MSSA (ATCC 25923), E. coli (ATCC 25922) $\left(10^{7} \mathrm{cfu} / \mathrm{mL}\right)$ in sterilized peptone water $(0.1 \mathrm{~g} / 100 \mathrm{~mL})$ and then incubated at $37^{\circ} \mathrm{C}$. After $0,30,60,90,120,180$ and 240 minutes of treatment, cells were collected then centrifuged at $3000 \mathrm{rpm}$. UV absorbance at $260 \mathrm{~nm}$ of the supernatant was measured using a spectrophotometer. A tube without bacteria in sterilized peptone water was used as control [23].

\section{Adherence of Bacterial Cells to Polystyrene}

Initial adherence of $M R S A$ (ATCC 43300) to polystyrene was determined using a previously reported method [24]. Briefly, bacteria were grown overnight in $10 \mathrm{~mL}$ TSB at $37^{\circ} \mathrm{C}$ and then diluted $1: 100$ in fresh TSB containing ASEO at the required concentration. A quantity of $5 \mathrm{~mL}$ of the bacterial suspensions was then poured into Petri dishes and incubated for $30 \mathrm{~min}$ at $37^{\circ} \mathrm{C}$. The plates were washed five times using $5 \mathrm{~mL}$ PBS, air dried and stained for $1 \mathrm{~min}$ with $0.4 \%$ crystal violet. The number of the adhered cells was determined microscopically (CETI 60243T UK) by counting the number of bacteria in 20 fields of view. The essential oil concentrations tested were $1 / 10$ of $\mathrm{MIC}, 1 / 2 \mathrm{MIC}$, and the MIC concentration. Adherence was calculated as the total number of cells adhered per square centimetre examined. Each ASEO concentration was assayed in triplicate and the adherence of ASEO treated cells compared with untreated controls. Assays were performed three times on different days and the same result was obtained for each occasion.

\section{Statistical analysis}

All experiments were done in triplicate. The obtained results are expressed as mean values with the standard error. The statistical analyses were performed using Student's t-test to compare the controls and treated samples at a significance level of $5 \%$.

\section{RESULTS}

\section{$\mathrm{MIC}$ and $\mathrm{MBC}$ results}

Table 1 shows the MIC and MBC results of ASEO. The MIC values were in the range of 250-1000 $\mu \mathrm{g} / \mathrm{ml}$. Regarding MIC, the most susceptible isolates were $S$. epidermidis (ATCC12228) and S. epidermidis (ATCC 35984) with MIC value of $250 \mu \mathrm{g} / \mathrm{ml}$, while the most resistant strain were MRSA (ATCC 43300) with MIC value of $1000 \mu \mathrm{g} / \mathrm{ml}$. The MBC values were in the range of $500-2000 \mu \mathrm{g} / \mathrm{ml}$. 
The most susceptible isolate in MIC and MBC was $S$. epidermidis (ATCC12228) with MBC of $500 \mu \mathrm{g} / \mathrm{ml}$, while the most resistant $\mathrm{MBC}$ was $M R S A$ (ATCC 43300) with $\mathrm{MBC}$ value of $2000 \mu \mathrm{g} / \mathrm{ml}$. MBC values are higher than MIC values for all tested strains.

Table 1. MIC and MBC of Achillea santolina $(\mu \mathrm{g} / \mathrm{ml})$ for the bacterial isolates

\begin{tabular}{|c|l|c|c|}
\hline Isolate Number & \multicolumn{1}{|c|}{ Isolate name } & $\mathrm{MIC} \mu \mathrm{g} / \mathrm{ml}$ & $\mathrm{MBC} \mu \mathrm{g} / \mathrm{ml}$ \\
\hline 1 & S. epidermidis (ATCC 35984) & 250 & 1000 \\
\hline 2 & MSSA (ATCC 25923) & 500 & 1000 \\
\hline 3 & MRSA (ATCC 43300) & 500 & 2000 \\
\hline 4 & P. aeruginosa (ATCC 27853) & 1000 & 1000 \\
\hline 5 & E. coli (ATCC 25922) & 500 & 1000 \\
\hline 6 & S. epidermidis (ATCC 12228) & 250 & 500 \\
\hline
\end{tabular}

\section{MBIC and MBEC for the bacterial isolates}

The results of MBIC and MBEC of Achillea santolina are shown in Table 2. The MBIC test revealed that the values of this test were in the range of 500-2000 $\mu \mathrm{g} / \mathrm{ml}$. The most susceptible isolate was $S$. epidermidis (ATCC 12228), with MBIC value of $500 \mu \mathrm{g} / \mathrm{ml}$, while the most resistant strains were MRSA (ATCC 43300) and P. aeruginosa (ATCC 27853) with MBIC values of $2000 \mu \mathrm{g} / \mathrm{ml}$.

The MBEC test results show that values for this test were in the range of $500-4000 \mu \mathrm{g} / \mathrm{ml}$. The most susceptible isolate was $S$. epidermidis (ATCC12228) with MBEC of $500 \mu \mathrm{g} / \mathrm{ml}$ while the most resistant were $M R S A$ and $P$. aeruginosa (ATCC 27853) with MBEC of $4000 \mu \mathrm{g} / \mathrm{ml}$. The MBEC values are higher compared to MBIC values for all tested strains.

Table 2. MBIC and MBEC of Achillea santolina $(\mu \mathrm{g} / \mathrm{ml})$ for the bacterial isolates

\begin{tabular}{|c|l|c|c|}
\hline Isolate Number & \multicolumn{1}{|c|}{ Isolate name } & MBIC $\mu \mathrm{g} / \mathrm{ml}$ & MBEC $\mu \mathrm{g} / \mathrm{ml}$ \\
\hline 1 & S. epidermidis (ATCC 35984) & 1000 & 2000 \\
\hline 2 & MSSA (ATCC 25923) & 1000 & 2000 \\
\hline 3 & MRSA (ATCC 43300) & 2000 & 4000 \\
\hline 4 & P. aeruginosa (ATCC 27853) & 2000 & 4000 \\
\hline 5 & E. coli (ATCC 25922) & 1000 & 2000 \\
\hline 6 & S. epidermidis (ATCC12228) & 500 & 500 \\
\hline
\end{tabular}

\section{Leakage of Potassium Ion}

Four bacterial strains were used to measure cell membrane permeability based on leakage of potassium ions: S. epidermidis (ATCC 35984), MRSA (ATCC 43300), $P$. aeruginosa (ATCC 27853), and E. coli (ATCC 25922). When bacterial strains were treated with ASEO at the MIC concentration, a sharp increase in potassium ions leakage was observed as shown in Figure 2. All tested bacterial strains treated with ASEO showed increased leakage of $\mathrm{K}^{+}$ ions with time, and there is a sharp increase in leakage of potassium ions with increase in incubation time as shown in Figure 2. Herein, the extracellular potassium ions concentrations increased from $50 \mu \mathrm{M}$ to about $300 \mu \mathrm{M}$ in all tested bacterial strains.
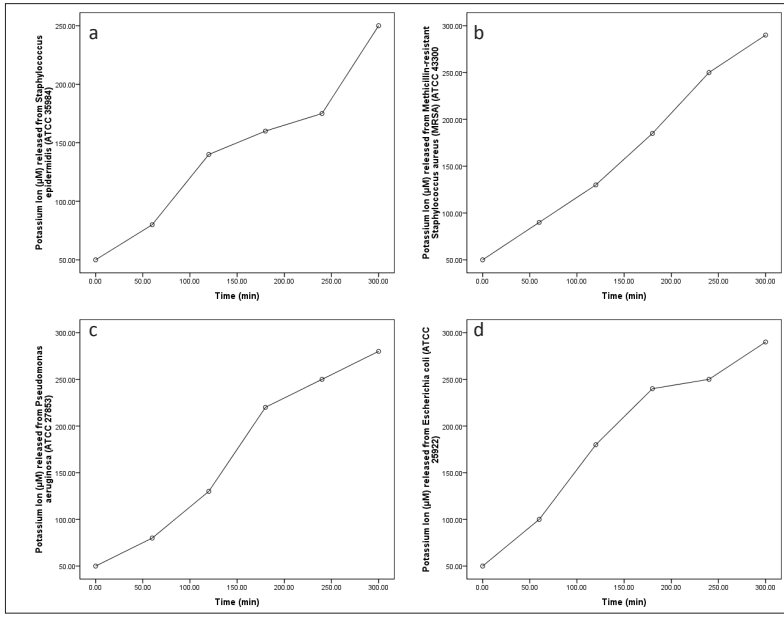

Figure 2. Effect of ASEO on potassium release of: a. S. epidermidis (ATCC 35984), b. MRSA (ATCC 43300), c. P. aeruginosa (ATCC 27853), d. E. coli (ATCC 25922)

\section{Integrity of the Cell Membrane (Release of cellular material)}

Cellular materials release, especially of DNA and RNA, to outside the cell is another test that indicates damage to the cell membrane. When $S$. epidermidis (ATCC12228), MSSA (ATCC 25923), and E. coli (ATCC 25922) were treated at MIC concentration of ASEO, there was a continual increase in $260 \mathrm{~nm}$ absorption over the incubation time (Figure 3). There was also elevated release of cell materials according to time of exposure in all tested bacterial strains.
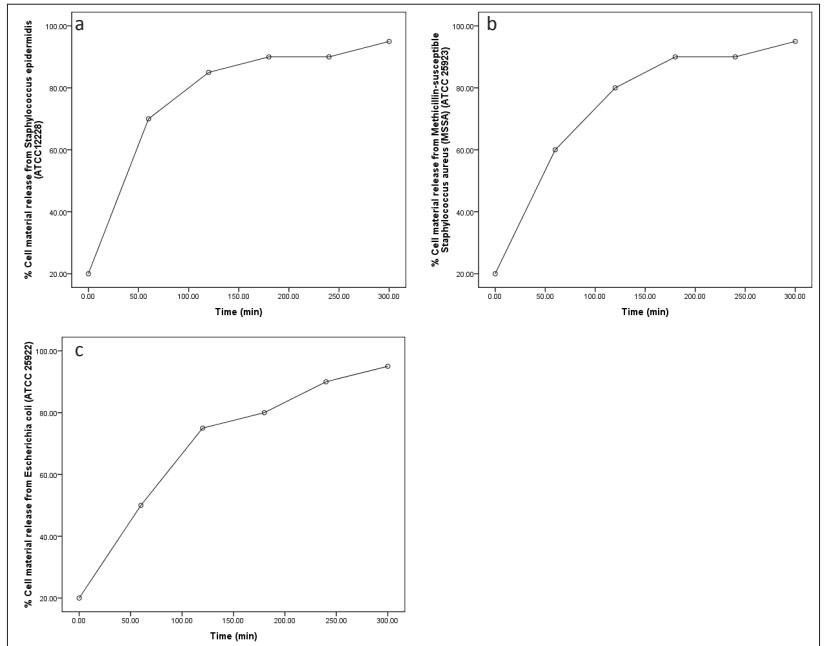

Figure 3. Effect of ASEO on cell material release of: a. S. epidermidis (ATCC12228), b. MSSA (ATCC 25923), c. E. coli (ATCC 25922)

\section{Adherence of Bacterial Cells to Polystyrene}

Optical density 600 (OD600) was used to measure the planktonic growth, while OD490 was used to measure biofilm growth. The essential oil concentrations tested were $1 / 10$ of MIC, 1/2 MIC, and the MIC concentration. Adding ASEO to polystyrene Petri dishes containing a suspension culture of the MRSA (ATCC 43300) strain reduced the number of individual cells adhering to the polystyrene surface after 30 minutes incubation period (Figure 4). The number of adhered bacteria also decreased with increase in the concentrations of ASEO. 


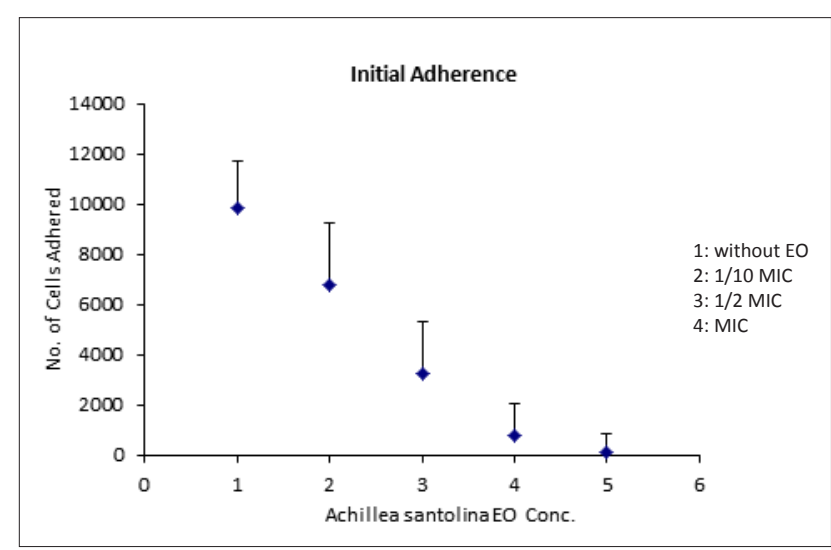

Figure 4. Effect of ASEO on initial adhesion of MRSA (ATCC 43300); 1: without EO, 2: 1/10'MIC, 3: 1/2'MIC, 4: MIC

\section{DISCUSSION}

Essential oils are complex volatile compounds that have been used in traditional medicine for treatment of many different diseases. These oils are known to have antibacterial, antifungal and antiviral activity beside their antioxidant effects.

In the present study, the results of MIC determination showed that essential oil of Achillea santolina exhibits potent activities against all tested bacteria, with MIC values ranging from 250 to $1000 \mu \mathrm{g} / \mathrm{ml}$ and MBIC values between $500-2000 \mu \mathrm{g} / \mathrm{ml}$. The results clearly indicate that essential oil of Achillea santolina was able to overcome the resistance shown by all tested microorganisms and their biofilm - especially MRSA (ATCC 43300) and P. aeruginosa (ATCC 27853). One of the best chemical properties of essential oil is hydrophobicity. Essential oils are hydrophobic which allows them to penetrate into microbial cells - causing disturbance to their structure that result in increased cellular leakage and death.

MRSA poses a significant problem due to its resistance to most known antibiotics. Recently, its resistance to vancomycin has become noted with alarm, as this antibiotic is relied upon for treating MRSA infections [25]. MRSA is a leading cause of endocarditis, bacteraemia, osteomyelitis and skin and soft tissue infections. Infections induced by MRSA causes increased morbidity and mortality, besides longer hospitalizations. The formation of biofilms by MRSA increases its ability to resist antibiotics. MRSA biofilm infections include hospital-acquired infections, artificial heart valves, urinary tract infections and catheter infections [26].

The most distinguishing challenge with $P$. aeruginosa is its ability to rapidly develop resistance during the course of treating an infection. P. aeruginosa is responsible for $30 \%$ of all pneumonias, $19 \%$ of all urinary tract infections, and $10 \%$ of all bloodstream infections [27]. The basic bacterial mechanisms of resistance include acquired resistance genes, express efflux systems and modification of drug target site.

The antibacterial activity of ASEO is attributed to its components such as terpinen-4-ol, cis-sabinene hydrate, 1,8-cineole, $\alpha$-cadinol, $\alpha$-terpinol, camphor and p-cymene. Terpinen-4-ol has also been found to be one of the major ASEO constituents (10.6\%), and Terpinen-4-ol was discovered to be active against clinical skin isolates of MRSA [28].
Terpinen-4-ol is an amphipathic molecule and its activity target is believed to be the cell membrane. Terpinen-4-ol, therefore, has enough hydrophilicity to diffuse through the surrounding water to reach the bacterial cytoplasmic membrane, and enough hydrophobicity to penetrate through the bacterial cell membrane [29].

Cis-sabinene hydrate is another major component of ASEO. This constitutes $10.64 \%$ of the total oil. Ramos et al. [30] concluded that cis-sabinene hydrate in the essential oil of Origanum majorana was the most active ingredient and was the one responsible for inhibition of tested bacterial growth. The terpene 1,8-cineole is a natural monoterpene (terpene oxide), also known as eucalyptol, and is non-toxic to tissue. Clinical trials have found strong evidence that 1,8-cineole has anti-inflammatory activity [31]. Moreover, 1,8-cineole inhibits the leukotrienes (LTB4) and PGE2 that are generated from the pathways of the arachidonic acid metabolism [32]. It is also often used in the treatment of bronchitis, sinusitis and rheumatism [33]. Constituting $4.69 \%$ of the total ASEO, $\alpha$-cadinol has been reported to have antimicrobial and antitumor activities in a variety of cell lines [34,35].

The terpene $\alpha$-Terpinol makes up $3.97 \%$ of the total extracted oil, and has been reported to have a strong antimicrobial activity. It is believed that $\alpha$-Terpinol disrupts the cytoplasmic membrane, increases its permeability and depolarizes its potential [33].Camphor composes 2.01\% of the total ASEO, and has been reported to have antimicrobial, antiviral and anticancer activities [36]. The terpene p-cymene shows a diverse range of activity, including antimicrobial, antioxidant, anti-inflammatory and anticancer effects. It has been reported that $p$-cymene targets several sites in the cell - notably the cell membrane and mitochondria. The mechanism of action of $p$-cymene involve alteration in the lipid of the plasma membrane that results in disrupting the cytoplasmic membrane permeability and fluidity [37].

The mechanism of action of ASEO depends on their chemical composition, and their antimicrobial activity is not attributable to a single mechanism, but is instead a series of reactions involving the entire bacterial cell. Studies have reported the synergistic effect between constituents of essential oils against different pathogens. The primary target for ASEO, as it can be concluded from its constituents, is the cell membrane - resulting in loss of integrity and increased permeability.

The results of this study showed increased leakage of potassium ions and increased leakage of $260 \mathrm{~nm}$ absorbing cellular materials. These results indicate that the cell membrane structure was damaged by essential oil application, as compared to the control group. Furthermore, the results indicate that the subinhibitory levels of ASEO markedly reduced the number of MRSA (ATCC 43300) cells adhered to polystyrene. It is believed that the subinhibitory level of ASEO caused damage and changes to the cell membrane of MRSA (ATCC 43300) and prevented it from adhering to the polystyrene surface.

The activity of essential oil may not be attributed to any particular major constituents [38,39]. Sometimes the minor components of essential oil can be important. The overall 
activity of essential oil may be attributed to synergistic effects of several chemical constituents [40-42].

\section{CONCLUSION}

ASEO showed high antibacterial and antibiofilm activity and were able to inhibit initial adherence of tested bacteria at sub-inhibitory concentrations.

\section{FUNDING}

This work was supported by the Deanship of Scientific Research, Mutah University, Mutah, Jordan (grant numbers 120/14/63, 16/02/2015).

\section{ORCID iDs}

Jehad Al-Shuneigat (Dhttps://orcid.org/0000-0002-8948-8385 Sameeh Al-Sarayreh (Dhttps://orcid.org/0000-0002-7734-2055 Yousef Al-Saraireh (1)https://orcid.org/0000-0002-8120-9118

\section{REFERENCES}

1. Esguerra EM. Super bugs and antimicrobial stewardship. Mo Med. 2017;438:114-6

2. Ventola CL. The Antibiotic Resistance Crisis. P\&T. 2015;40:277-83.

3. Doulam RM, Costerton JW. Biofilms: Survival mechanisms of clinically relevant microorganisms. Clin Microbiol Rev. 2002; 15:167-93.

4. Mah TFC, O’Toole G A. Mechanisms of biofilm resistance to antimicrobial agents. Trends Microbiol. 2001;9:34-9.

5. Costerton JW, Stewart PS, Greenberg EP. Bacterial biofilms: a common cause of persistent infections. Science. 1999;284:1318-22.

6. Hoiby N, Bjarnsholt T, Givskov M, Molin S, Ciofu O. Antibiotic resistance of bacterial biofilms. Int J Antimicrob Agents. 2010; 35:322-32.

7. Luppens SB, Rombouts FM, Abee T. The effect of the growth phase of Staphylococcus aureus on resistance to disinfectants in a suspension test. J Food Prot. 2002;65:124-9.

8. Gupta K, Marques CNH, Petrova OE, Sauer K. Antimicrobial tolerance of Pseudomonas aeruginosa biofilms is activated during an early developmental stage and requires the two-component hybrid Sag S. J Bacteriol. 2013;195:4975-87.

9. Cramton SE, Gerke C, Schnell NF, Nichols WW, Gotz F. The intercellular adhesion (ica) locus is present in Staphylococcus aureus and is required for biofilm formation. Infect Immunity. 1999; 67:5427-33.

10. Drenkard E. Antimicrobial resistance of Pseudomonas aeruginosa biofilms. Microbes Infect. 2003;5:1213-9.

11. Marshall KC. Biofilms: An overview of bacterial adhesion, activity, and control at surfaces. ASM News. 1992;58:202-7.

12. Carpentier B, Cerf O. Biofilms and their consequences, with particular reference to hygiene in food industry. J Appl Bacteriol. 1993;75:499-511.

13. Sauer K, Camper AK, Ehrlich GD, Costerton JW, Davies DG. Pseudomonas aeruginosa displays multiple phenotypes during development as a biofilm. J Bacteriol. 2002;184:1140-54.

14. Khayyat SA, Roselin S. Recent progress in photochemical reaction on main components of some essential oils. J Saudi Chem Soc. 2018; 22:855-75

15. Bimbiraite K, Ragazinskiene O, Maruska A, Kornysova O. Comparison of the chemical composition of four yarrow (Achillea millefolium L.) morphotypes. Biologija. 2008;54:208-12.

16. Cowan MM. Plant products as antimicrobial agents. Clin Microbiol Rev. 1999;12:564-82.

17. Bakera SJ, Paynea DJ, Rappuolib R, De Gregorio E. Technologies to address antimicrobial resistance. PNAS. 2018;115:12887-95

18. Burt S. Essential oils: their antibacterial properties and potential applications in foods-a review. Int J Food Microbiol. 2004;94:223-53.
19. Al-Shuneigat J, Al- Sarayreh S, Al-Qudah M, Al-Saraireh Y, Al-Tarawneh I. Chemical composition and antioxidant activity of essential oil of Achillea santolina. IJONS. 2019;10:17694-701.

20. Rachid S, Ohlsen K, Witte W, Hacker J, Ziebuhr W. Effect of subinhibitory antibiotic concentrations on polysaccharide intercellular adhesion expression in biofilm-forming Staphylococcus epidermidis. Antimicrob Agents Chemother. 2000;44:3357-63.

21. Jardak M, Elloumi-Mseddi J, Aifa S, Mnif S. Chemical composition, anti-biofilm activity and potential cytotoxic effect on cancer cells of Rosmarinus officinalis L. essential oil from Tunisia. Lipids Health Dis. 2017;16:1-10

22. Ceri H, Olson M, Morck D, Storey D, Read R, Buret A, Olson B. The MBEC Assay System: multiple equivalent biofilms for antibiotic and biocide susceptibility testing. Methods Enzymol. 2001;337:377-85.

23. Yang XN, Khan I A, Kang SC. Chemical composition, mechanism of antibacterial action and antioxidant activity of leaf essential oil of Forsythia koreana deciduous shrub. Asian Pac J Trop Med. 2015;8:694-700.

24. Heilmann C, Gerke C, Premington FP, Gotz F. Characterization of Tn917 insertion mutant of Staphylococcus epidermidis affected in biofilm formation. Infect Immun. 1996;64:277-82.

25. Turner NA, Sharma- Kuinkel BK, Maskarinec SA, Eichenberger EM, Shah PP, Carugati M, Holland TL, Fowler VG. Methicillin- resistant Staphylococcus aureus: an overview of basic and clinical research. Nat Rev Microbiol. 2019;17:203-18

26. Gunther F, Blessing B, Tacconelli E, Mutters NT. MRSA decolonization failure-are biofilms the missing link. Antimicrob Resist Infect Control. 2017;6:1-7

27. Lister PD, Wolter DJ, Hanson ND. Antibacterial-Resistant Pseudomonas aeruginosa: clinical impact and complex regulation of chromosomally encoded resistance mechanisms. Clin Microbiol Rev. 2009;22:582-610.

28. Loughlin R, Gilmore BF. McCarron PA, Tunney MM. Comparison of the cidal activity of tea tree oil and terpinen-4-ol against clinical bacterial skin isolates and human fibroblast cells. Lett Appl Microbiol. 2008;46;428-33

29. Carson CF, Mee BJ, Riley TV. Mechanism ofaction of Melaleuca alternifolia (tea tree) oil on Staphylo-coccus aureus determined by time-kill, lysis, leakage, andsalt tolerance assays and electron microscopy. Antimicrob Agents Chemother. 2002;46:1914-20.

30. Ramos S, Rojas LB, Lucena ME, Meccia G, Usubillaga A. Chemical composition and antibacterial activity of Origanum majorana L. Essential oil from the Venezuelan Andes. J Essent Oil Res. 2011; 23:45-9.

31. Brown SK, Garver WS, Orlando RA. 1,8-cineole: An underappreciated anti-inflammatory therapeutic. J Biomol Res Ther. 2017;6;1-6.

32. Yoon HS, Moon SC, Kim ND, Park BS, Jeong MH, Yoo YH. Genistein induces apoptosis of RPE-J cells by opening mitochondrial PTP. Biochem Biophys Res Commun. 2000;276:151-6

33. Li L, Li ZW, Yin ZQ, Wei Q, Jia RY, Zhou LJ, et al. Antibacterial activity of leaf essential oil and its constituents from Cinnamomum longepaniculatum. Int J Clin Exp Med. 2014;15;7:1721-7.

34. Tao L, Zhou L, Zheng L, Yao M. Elemene displays anti-cancer ability on laryngeal cancer cells in vitro and in vivo. Cancer Chemother Pharmacol. 2006;58:24-34.

35. Sua YC, Hsub KP, Wangb EIC, Hob CL. Composition, in vitro cytotoxic, and antimicrobial activities of the flower essential oil of diospyros discolor from Taiwan. Nat Prod Commun. 2015;10:1311-4.

36. Chen W, Vermaak I, Viljoen A. Camphor-A fumigant during the black death and a coveted fragrant wood in ancient. Molecules. 2013;18:5434-54

37. Custodio JBA, Ribeiro MV, Silva FCG, Machado M, Sousa MC. The essential oils component p-cymene induces proton leak through Fo-ATP synthase and uncoupling of mitochondrial respiration. $J$ Exp Pharmacol. 2011;3:69-76

38. Nazzaro F, Fratianni F, De Martino L, Coppola R, De Feo V. Effect of essential oils on pathogenic bacteria. Pharmaceuticals. 2013;6:1451-74.

39. Swamy MK, Akhtar MS, Sinniah UR. Antimicrobial properties of plant essential oils against human pathogens and their mode of action: an updated review. Evid-Based Complementary Altern Med. 2016;2016:1-21. 
40. Isman $\mathrm{MB}, \mathrm{Wilson} \mathrm{JA}$, Bradbury R. Insecticidal activities of commercial rosemary oils (Rosmarinus officinalis.) against larvae of Pseudaletia unipuncta. and Trichoplusia ni. in relation to their chemical compositions. Pharm Biol. 2008;46:82-7.

41. Al-Shuneigat J, Al- Sarayreh S, Al-Saraireh Y, Al-Qudah M, Al-Tarawneh I. Effects of wild Thymus vulgaris essential oil on clinical isolates biofilm-forming bacteria. IOSR- JDMS. 2014;13:62-6.
42. Al-Shuneigat J, Al-Tarawneh I, Al-Qudah M, Al-Sarayreh S, Al-Saraireh Y. In vitro antibiofilm effect of Ruta graveolens essential oil. IJONS. 2015;5:4070-6. 